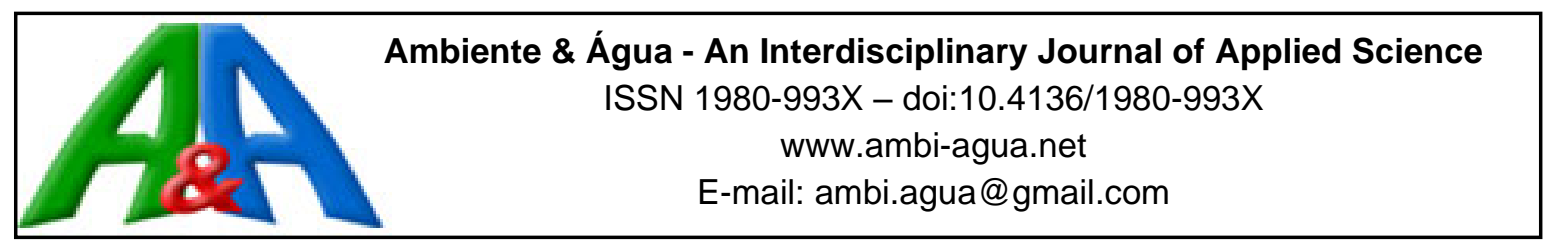

\title{
Climate change impact assessment in a tropical headwater basin
}

\author{
ARTICLES doi:10.4136/ambi-agua.2753
}

Received: 19 May 2021; Accepted: 17 Dec. 2021

\begin{abstract}
Vinícius Siqueira Oliveira Carvalho ${ }^{1}$; ;ívia Alves Alvarenga ${ }^{2 *}$; Pâmela Aparecida Melo ${ }^{\circledR}$; Javier Tomasella ${ }^{3 \oplus}$; Carlos Rogério de Mello ${ }^{\circledR}$; Minella Alves Martins 3 (iD

${ }^{1}$ Instituto de Recursos Naturais. Universidade Federal de Itajubá (UNIFEI), Avenida BPS, n ${ }^{1303,}$ CEP: 37500-903, Itajubá, MG, Brazil. E-mail: vsiqueira18@unifei.edu.br ${ }^{2}$ Departamento de Recursos Hídricos e Saneamento. Universidade Federal de Lavras (UFLA), Caixa Postal 3037, CEP: 37200-900, Lavras, MG, Brazil. E-mail: pam.melo.al@gmail.com, crmello@ufla.br ${ }^{3}$ Coordenação Geral de Pesquisa e Desenvolvimento. Centro Nacional de Monitoramento e Alertas de Desastres Naturais (Cemaden), Rodovia Presidente Dutra, Km 40, SP-RJ, CEP: 12630-000, Cachoeira Paulista, SP, Brazil. E-mail: javier.tomasella@cemaden.gov.br, minella.martins@gmail.com *Corresponding author. E-mail: livia.aalvarenga@ufla.br
\end{abstract}

\begin{abstract}
Changes in precipitation and air temperature may produce different impacts on the hydrological regime, compromising water supply. This study focuses on climate change impacts in the Verde River Basin (VRB), a tropical headwater basin in southeast Brazil, located in the state of Minas Gerais. The Variable Infiltration Capacity model (VIC) was calibrated and validated in the Verde River Basin. The downscaling (Eta Regional Climate Model, at 20-km resolution) of three Global Circulation Models (CanESM2, HadGEM2-ES and MIROC5) were used to drive the VIC for a historical baseline (1961-2005) and three time-slices (2011-2040, 2041-2070 and 2071-2099), under RCPs 4.5 and 8.5 scenarios. The scenarios were used as input in the hydrological model after bias correction. The hydrological model (VIC) showed satisfactory statistical performance in calibration and validation, with CNS varying from 0.77 to 0.85 for daily and monthly discharges; however, it overestimated some peak flows and underestimated the recession flows. Multi-model ensemble means predict increases of the minimum and maximum monthly average temperature for the investigated area at the end of the century. The Eta-CanESM2 indicated greater warming, mainly for RCP8.5 at the end the century, whereas Eta-HadGEM2-ES showed higher reduction in the precipitation for RCP4.5 at the beginning of the century and for RCP8.5 at the end the century, negatively impacting the evapotranspiration and discharge. Among the Regional Climate Models (RCMs), the EtaMIROC5 showed minor changes in the components of the hydrological cycle. This study suggests that Global Circulation Models represent an additional uncertainty, which should be accounted for in the climate change impact assessment.
\end{abstract}

Keywords: climate changes, RCP4.5, RCP8.5, VIC model.

\section{Avaliação do impacto da mudança climática em uma bacia hidrográfica tropical de cabeceira}

\section{RESUMO}

Mudanças na precipitação e na temperatura do ar podem produzir diferentes impactos no

(c) (1)

This is an Open Access article distributed under the terms of the Creative Commons Attribution License, which permits unrestricted use, distribution, and reproduction in any medium, provided the original work is properly cited. 
regime hidrológico, causando colapso no abastecimento de água. Este estudo focaliza nos impactos das mudanças climáticas na bacia do Rio Verde (VRB), uma bacia hidrográfica de cabeceira no sudeste do Brasil, localizada em Minas Gerais. O modelo hidrológico Variable Infiltration Capacity (VIC) foi calibrado e validado na bacia do Rio Verde. O downscaling (Modelo de Clima Regional Eta, com resolução de $20 \mathrm{~km}$ ) de três Modelos de Circulação Global (CanESM2, HadGEM2-ES e MIROC5) foram usados no VIC com dados históricos (1961-2005) e em três intervalos de tempo (2011- 2040, 2041-2070 e 2071-2099), nos cenários RCPs 4.5 e 8.5. Os cenários foram usados como entrada no modelo hidrológico após a correção do viés. O modelo hidrológico (VIC) apresentou desempenho estatístico satisfatório na calibração e validação, com CNS variando de 0,77 a 0,85 para as vazões diárias e mensais; no entanto, superestimou alguns fluxos de pico e subestimou os de recessão. A média do conjunto de modelos prevê aumentos da temperatura média mensal mínima e máxima no final do século. O Eta-CanESM2 indicou maiores temperaturas, principalmente para RCP8.5 no final do século, enquanto Eta-HadGEM2-ES apresentou a maior redução na precipitação para RCP4.5 no início do século e para RCP8.5 no final do século, impactando negativamente na evapotranspiração e vazão. Entre os Modelos Climáticos Regionais (MCRs), o Eta-MIROC5 apresentou pequenas alterações nos componentes do ciclo hidrológico. Este estudo sugere que Modelos de Circulação Global representam incertezas adicionais, que devem ser consideradas na avaliação do impacto das mudanças climáticas.

Palavras-chave: modelo VIC, mudanças climáticas, RCP4.5 e RCP8.5.

\section{INTRODUCTION}

Changes in precipitation and air temperature associated with greenhouse gas emission increases have been studied through simulations accomplished by Global Climate Models (GCM). These simulations are essential for understanding future climate change and represent temporal and spatial variability of the climate in a land-ocean-atmosphere system (Chou et al., 2014a; Oliveira et al., 2017).

However, the study of climate change on the regional scale depends on regional physical processes and geographical characteristics, thus, the downscaling of the GCM simulations (Regional Climate Models, RCM) have been applied to assess regional hydrological variations caused by climate change (Rajib and Rahman, 2012; Chou et al., 2014b). Regional hydrological responses to global climate change are strategic for water-resource management, agricultural and energy production, water availability, and for flooding and drought forecasting (Byun et al., 2019).

Based on the Intergovernmental Panel on Climate Change (IPCC) 5th Assessment Report (AR5) (IPCC, 2014), the increase in global mean temperatures for 2081-2100 relative to 19862005 are limited in the range from 0.3 to $1.7^{\circ} \mathrm{C}(\mathrm{RCP} 2.6), 1.1$ to $2.6^{\circ} \mathrm{C}(\mathrm{RCP} 4.5), 1.4$ to $3.1^{\circ} \mathrm{C}$ (RCP6.0), and 2.6 to $4.8^{\circ} \mathrm{C}$ (RCP8.5). The potential impacts of climate change on hydrological regimes have been discussed widely.

Worldwide, numerous studies have applied the Variable Infiltration Capacity (VIC) hydrological model to study effects of climate change on the hydrological cycle (Chawla and Mujumdar, 2015; Bozkurt et al., 2017; Wang et al., 2019; Yang et al., 2019; Dang et al., 2020). Wang et al. (2019) assessed the impact of climate change on hydropower potential in the Nanliujiang River Basin, China, considering five GCMs under all RCPs scenarios. Dang et al. (2020) analyzed the effect of future climate on discharges in the upper Mekong River Basin, China, for five GCMs under RCPs 4.5 and 8.5 for the two selected models calibrated without and with reservoirs. Bozkurt et al. (2017) applied the VIC model driven by 26 GCMs under RCP8.5 to analyze the impact of climate change on four basins in Andes Cordillera, Chile.

Rev. Ambient. Água vol. 17 n. 1, e2753 - Taubaté 2022 
Chawla ad Mujumdar (2015) examined the effects of climate change on discharge in the Upper Ganga Basin, India, for 6 GCMs under RCPs 4.5 and 8.5. Yang et al. (2019) assessed future climate change effects on extreme discharges in the Yangtze River, China, using seven GCMs under the highest emission scenario (RCP8.5). Global Circulation Models could impact the magnitude and change direction of hydrological response. A multi-model ensemble approach can improve the reliability of model predictions and better assess the hydrological modeling uncertainty.

In Brazil, the Grande River Basin (GRB), in the southeastern region, is essential for hydropower generation due to topography and abundant water availability, being, therefore, highly vulnerable to climate change (Alvarenga et al., 2017). Some studies have investigated the impacts of climate change on the Grande River Basin headwater, indicating that both temperature and precipitation affect the discharge and total runoff magnitude (Viola et al., 2015; Alvarenga et al., 2016b; 2018; Oliveira et al., 2017). In this region, these studies compared climate impacts on the future water cycle with Eta-HadGEM2-ES and MIROC5 inputs (Alvarenga et al., 2016b; 2018; Oliveira et al., 2017).

As reported by Alvarenga et al. (2016b), who used the Distributed Hydrology Soil Vegetation Model (DHSVM), the simulated discharge over the 21st century in a small watershed in Mantiqueira Range region (Grande River headwaters) indicated drastic changes under the RCP8.5 scenario, with reduction of mean monthly and annual discharge of 77 and $69 \%$, respectively. In another study carried out at the same region, Oliveira et al. (2017) used the Soil and Water Assessment Tool (SWAT) hydrological model to assess the impacts of climate change on discharge and hence on hydropower potential, verifying mean monthly discharge reduction from 49.6 to $69.4 \%$ for RCP8.5, which implies serious problems in the potential of hydroelectricity generation. Viola et al. (2015), using the Lavras Simulation of Hydrology (LASH) model forced by A1B scenario emission (4th Assessment Report, AR4), simulated the hydrological changes in four headwater basins of the Grande River, wherein the results showed a reduction in the annual discharge for the first time-slice (2011-2040) and a substantial increase after 2041. In AR4, the A1B scenario is considered an intermediate scenario between high (A2 scenario) and low (B2 scenario) greenhouse gas emissions.

Independent of the considered scenario, it is well known that the water supply is closely related to climate patterns. In this way, climate changes modify the rainfall regime and increase the occurrence of extreme hydrological events, such as maximum discharges and long periods of drought. According to Nobre et al. (2011), although there is a considerable level of uncertainty regarding precipitation projections, there is significant convergence in the scenarios of a generalized increase in average air temperature and the frequency of heatwaves and hot nights (Marengo, 2007), thus impacting and consistently increasing water loss through evaporative processes and contributing to reduced water availability.

In this context, this research evaluated the hydrological impacts projected by two future scenarios (RCP4.5 and RCP8.5) using the downscaling of three GCMs (CanESM2, HadGEM2ES and MIROC5) by the Eta Regional Climate Model, in the Verde River Basin, southeast Brazil. The VIC model has been widely used worldwide at basin macro-scales and has proved to be an effective tool for assessing climate change effects on a hydrological cycle. The novelty in this research is applying the VIC model on a micro-scale in a tropical headwater basin and evaluating the impacts projected by different GCMs in the headwater Grande River Basin. In addition, in order to improve the reliability and robustness of future projections, ensembles of hydrological models will be evaluated.

The VIC model has been used in larger scales; however, calibrating and validating a smaller scale basin can be helpful for analyzing model performance in representing local hydrological processes, as headwater basins in Brazil are not as monitored as larger watersheds. Thus, extrapolating for a larger-scale is expected to facilitate parametrization. Besides model 
performance, the impacts of climate changes on smaller-scale can be helpful for management policies; i.e., the Rio Verde Basin (RVB) has its own Basin Committee, and it is responsible for administrating water uses.

\section{MATERIAL AND METHODS}

\subsection{Study Area}

The Verde River Basin (VRB) has a drainage area of approximately 4,100 km2, with an elevation ranging from 809 to $2,742 \mathrm{~m}$, and is located in the headwater of the Grande River Basin, draining to the Furnas Hydropower Plant Reservoir, which has an installed capacity of 1,216 MW, the most important facility in southeast Brazil (Figure 1). The Grande River Basin is an important Brazilian river for hydroelectric production in the country (Viola et al., 2014; Oliveira et al., 2018; Bueno et al., 2020). In this study, the wet season encompasses the period between October and March, while the dry season runs from April to September. The hydrological year extends from October to September of the following year.

According to the Köppen classification, Cwb predominates in the basin. The mean annual rainfall is approximately $1,500 \mathrm{~mm}$, and the annual mean temperature is $18^{\circ} \mathrm{C}$, with a dry winter season (Mello et al., 2012). The dominant soil classes in the highest parts of the Verde River Basin are Argisol (65.3\%), Latosol (23.3\%) and Cambisol (8.9\%), with rocky outcrops (1.3\%) and Fluvic Neosol (1.2\%) in the lower parts (watershed lowlands). Main land uses include Pasture (69.2\%), Forest (21.3\%), Eucalyptus (0.2\%), Agriculture (7\%) and Urbanization $(0.6 \%)$.

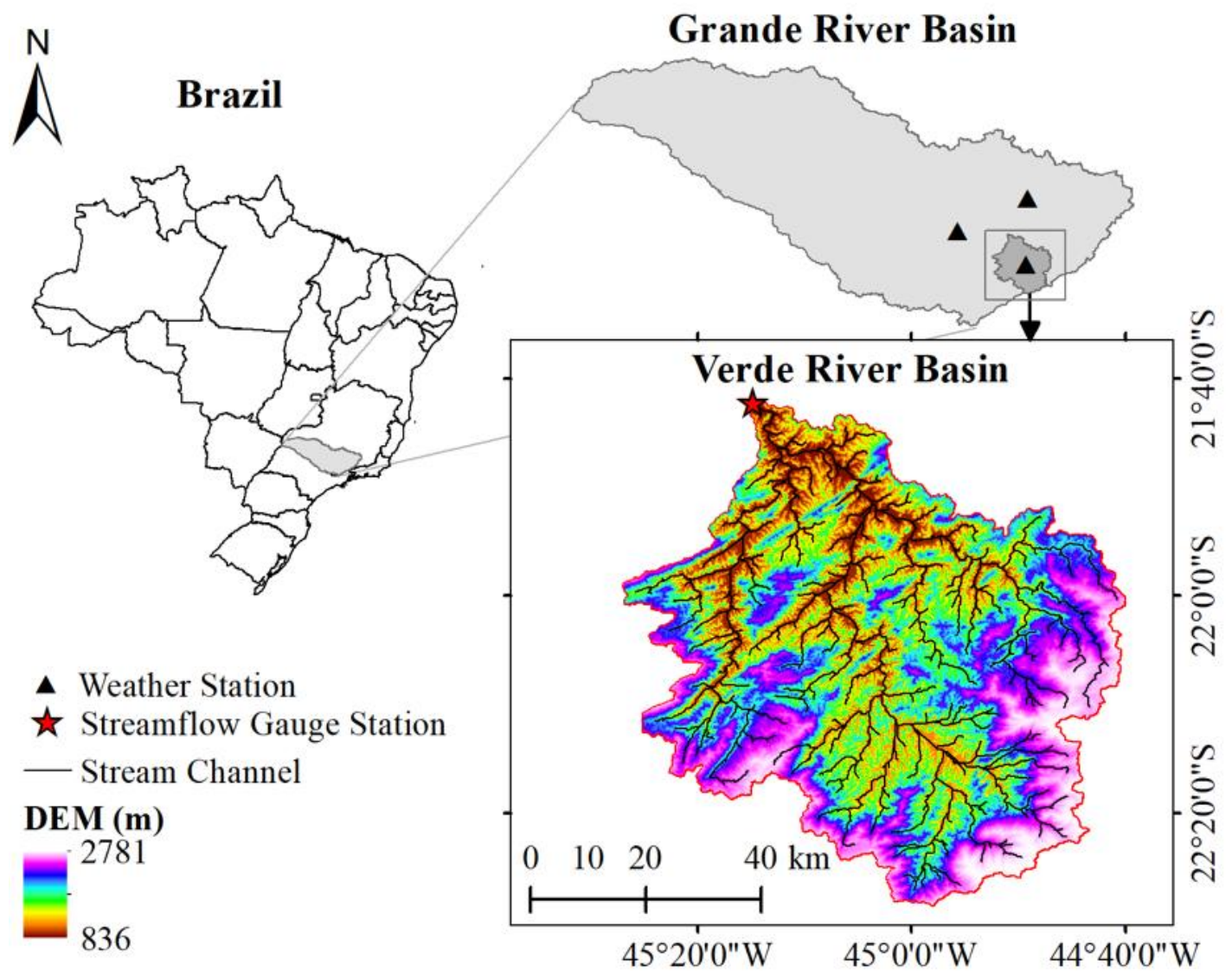

Figure 1. Geographical location of the Verde River Basin outlet in the Paraná River Basin and Grande River Basin, Minas Gerais state, southeast Brazil; and its Digital Elevation Model (DEM) and geographical location of the weather and streamflow gauge stations. 


\subsection{VIC model and set-up for the study area}

The VIC model is a grid-based macroscale semi-distributed land surface hydrological model, which consists of two modules: (i) rainfall-runoff (Liang et al., 1994; 1996; Liang and Xie, 2001) that simulates the water and energy fluxes that govern the terrestrial hydrological cycle; and (ii) routing model (Lohmann et al., 1996; 1998) that calculates the discharge using linearized de Saint-Venant equations.

The VIC model calculates water balance on grid cells using a three-layer soil column. In the upper soil layer, the variable soil moisture capacity curve controls infiltration and surface runoff, and the lower soil layer controls the baseflow generation, using ARNO model formulation (Todini, 1996).

The VIC model was manually calibrated and implemented at a spatial resolution of $0.01^{\circ}$ x $0.01^{\circ}$ (3768 grid cells), and daily and monthly temporal resolution. ASTER sensor data with a 30-m resolution was used to obtain the Digital Elevation Model (DEM). Images of the Landsat 8 sensor with 30-m resolution were used to obtain the land-use/cover map through supervised and object-oriented classification techniques, and the soil class map was provided by the State Foundation for the Environment. The atmospheric variables in the calibration phase (daily precipitation, maximum and minimum temperatures, and wind speed) were obtained from the meteorological stations of National Institute of Meteorology (Figure 1). The same variables were obtained from the climate models in the baseline period $(1961-2005)$ and in radiative forcing future scenarios $(2011-2099)$.

The study period, from 1990 to 2005, was divided into three parts: warm-up (1990-1992), calibration (1993-1999), and validation (2000-2005). The assessment of model performance was carried out using daily discharge data observed at the "Três Corações" gauge station, obtained from the National Water Agency and Basic Sanitation (Figure 1).

\subsection{Statistical tools for model evaluation and metrics for assessment of the hydrological changes}

In order to evaluate the VIC model performance in reproducing observed daily discharge, four precision statistics were calculated: (i) coefficient of determination $\left(\mathrm{R}^{2}\right)$ that describes the variance between simulated and observed discharge; (ii) Nash-Sutcliffe efficiency coefficient (CNS) that reflects the matching degree between simulated and observed discharge (Nash and Sutcliffe, 1970); (iii) Relative error (Pbias) that is employed to measure the mean tendency of the difference between simulated and observed discharges (Gupta et al., 1999); and (iv) KlingGupta efficiency (KGE) that is a decomposition of the CNS into three components: correlation coefficient (r), bias $(\beta)$, and variability $(\alpha)$ (Gupta et al., 2009).

KGE addressed by Gupta et al. (2009) relies upon two facts in using CNS to assess model performance: (i) bias is normalized by the standard deviation of the observed values, and for cases where the variability in the observed discharge is high, having less importance in the computation of CNS; and (ii) the maximum value of CNS is obtained when $\alpha=r$; therefore, since $\mathrm{r}$ will always be less than 1, when using CNS to evaluate performance of the model, we tend to select a value that underestimates the variability of discharge. According to Moriasi et al. (2007), $\mathrm{R}^{2}$ and CNS values greater than 0.50 are considered acceptable, and Pbias less than $|25 \%|$ presents satisfactory results.

In order to assess the VIC model capability to simulate discharge, when forced with climate models simulations, Flow Duration Curve (FDC) indices were used, following the "signature measures" of Yilmaz et al. (2008). To characterize the information in an FDC, we partitioned the curve into three different segments: (i) high-flow segment volume (MWH) with exceedance probabilities lower than 0.02 , which presents watershed response to large precipitation events; (ii) low-flow segment volume (MWL) with exceedance probabilities higher than 0.9, which shows long-term sustainability of discharge; and (iii) mid-segment slope (MS) with exceedance 
probabilities between 0.2 and 0.7 . Additionally, we appraised the seasonal variability between wet and dry season discharges (Season), according to Ley et al. (2011). For assessing climatic change, the variability between baseline period and radiative forcing scenarios (RCP4.5 and RCP8.5) was determined.

\subsection{Climate Models, Downscaling and Bias Correction}

The climate simulations used in this study were based on the dynamical downscaling of three GCMs (Table 1) simulations using the Eta regional climate model, referred to as EtaHadGEM2-ES, Eta-CanESM2, and Eta-MIROC5. According to Chou et al. (2014a; 2014b; 2018), in a study on South America, these models showed better performance in representing the current climate. It should be highlighted that uncertainty analysis inherent to climate change scenarios should consider several models (Knutti and Sedláček, 2013). Once uncertainties are inherent to the climate change projections, the impact assessments should prioritize multimodel climate projections to generate a range of plausible scenarios (Taylor et al., 2012). This multi-model approach is called "ensemble mean".

Table 1. Global circulation models (GCM) descriptions.

\begin{tabular}{lccl}
\hline GCM & $\begin{array}{c}\text { Horizontal resolution } \\
\text { (lat x long) }\end{array}$ & Vertical resolution & Reference \\
\hline CanESM2 & $2.75^{\circ} \times 2.8125^{\circ}$ & 35 levels & Arora et al. $(2011)$ \\
MIROC5 & $150 \mathrm{~km} \times 150 \mathrm{~km}$ & 40 levels & Watanabe et al. $(2010)$ \\
HadGEM2-ES & $1.274^{\circ} \times 1.875^{\circ}$ & 38 levels & Collins et al. $(2011)$ Martin et al. $(2011)$ \\
\hline
\end{tabular}

The Eta model has been adapted by the Center for Weather Forecast and Climate Studies for studies in Central and South America (Pesquero et al., 2010; Chou et al., 2012; Mesinger et al., 2012; Marengo et al., 2012). The vertical discretization at horizontal geodetic levels is critical for weather models, especially when applied in regions of steep topography (Mesinger et al., 2012). The atmosphere is represented vertically up to the pressure level of $25 \mathrm{hPa}$ with 38 layers (Black, 1994).

The downscaling method provided simulations with spatial resolution of $20-\mathrm{km}$ covering the period from 1961 to 2005 for baseline, and future scenarios (RCP4.5 and RCP8.5) that were divided in three time-slices: near-future (2011-2040), mid-century (2041-2070), and endcentury (2071-2099). The daily variables simulated by the Eta model used to assess the potential hydrological impacts on the Verde River Basin were precipitation, maximum and minimum temperatures, and wind speed.

However, simulations from RCMs, such as the Eta model, are subjected to systematic biases (Graham et al., 2007; Rodrigues et al., 2020), mainly caused by errors in conceptualization, discretization and spatial resolution of climate variables within a grid-cell (Teutschbein and Seibert 2012). Therefore, biases of RCM variables were corrected based on observed meteorological data from two stations within the Verde River Basin area. The linear scaling method was used for precipitation, maximum and minimum temperatures as proposed by Lenderink et al. (2007), and for wind speed as proposed by Haddeland et al. (2012). The corrections are based on the differences between mean data observed in meteorological stations and data simulated from RCM in the baseline period (Teutschbein and Seibert, 2012).

\subsection{Future Scenarios}

The RCP4.5 scenario represents a stabilization scenario, consolidating the radiative forcing at $4.5 \mathrm{~W} \mathrm{~m}^{-2}$ in the year 2100 (Thomson et al., 2011), and $\mathrm{CO}_{2}$ concentrations smaller than 550 
ppm (Wise et al., 2009). This scenario assumes that climate change policies are included in the countries' political-economic-social planning, as well as the development of technologies combined with the expansion of renewable energy (Thomson et al., 2011) and reduction of fossil fuel consumption and emissions (Clarke et al., 2007; Wise et al., 2009).

On the other hand, the RCP8.5 is the most pessimistic scenario for the 21 th century, with $\mathrm{CO}_{2}$ concentrations equivalent to $1370 \mathrm{ppm}$ (van Vuuren et al., 2011), following high disorderly growth demographic, low development of technologies to reduce pollution and the absence of public policies (Riahi et al., 2011). According to van Vuuren et al. (2011), the increase in energy demand and the excessive use of non-renewable energies, mainly mineral coal,characterize the worst scenario of greenhouse gas concentrations in 2100.

\section{RESULTS AND DISCUSSION}

\subsection{VIC Model Performance}

Table 2 shows the precision statistics values for calibration and validation for the daily and monthly discharges in a micro-scale tropical headwater basin. According to Moriasi et al. (2007), the statistical indices showed "good" and "satisfactory" performances of the VIC model for predicting the daily discharges in calibration and validation periods. The KGE presented as better than CNS for daily discharge for both calibration and validation periods, wherein the component representing the bias $(\beta)$ was dominant for better performance.

Table 2. Precision statistics of the VIC model for daily and monthly mean discharge.

\begin{tabular}{ccccc}
\hline \multirow{2}{*}{ Statistics Index } & \multicolumn{2}{c}{ Calibration (1993-1999) } & \multicolumn{2}{c}{ Validation (2000-2003) } \\
\cline { 2 - 5 } & Daily & Monthly & Daily & Monthly \\
\hline $\mathrm{R}^{2}$ & 0.85 & 0.92 & 0.85 & 0.91 \\
$\mathrm{CNS}$ & 0.79 & 0.85 & 0.77 & 0.80 \\
$\mathrm{Pbias}$ & 14.85 & 14.99 & 14.48 & 13.79 \\
KGE & 0.83 & 0.83 & 0.78 & 0.76 \\
\hline
\end{tabular}

The VIC model performance for Verde River Basin is similar to that in studies accomplished in the Grande River Basin headwater (Viola et al., 2014; Alvarenga et al., 2016a; Oliveira et al., 2017; 2018), as well as studies worldwide using this model for different purposes (Chawla and Mujumdar, 2015; Wang et al., 2019; Yang et al., 2019; Dang et al., 2020).

Daily hydrographs for calibration and validation periods are presented in Figure 2. The comparison between simulated and observed discharge shows overestimation in some peak flows and, for the recession period, the simulated discharges are underestimated. In general, other studies have shown difficulties in simulating peak and recession flows with different hydrological models. In studies in the Grande River Basin headwater, Viola et al. (2014) and Oliveira et al. (2017), using LASH and SWAT models, respectively, showed underestimation of the simulated discharges during the validation period. In the same region, Alvarenga et al. (2016b), applying the DHSVM model, presented underestimation during the dry season and overestimation during the wet season.

\subsection{Hydrologic responses to climate change}

Figure 3 shows projected changes of monthly hydrological variables (ensemble mean) including precipitation, maximum and minimum temperatures, evapotranspiration, total runoff and discharge for three time-slices (2011-2040, 2041-2070, and 2071-2099), under two emission scenarios (RCP4.5 and RCP8.5), relative to baseline period (1961 - 2005). 

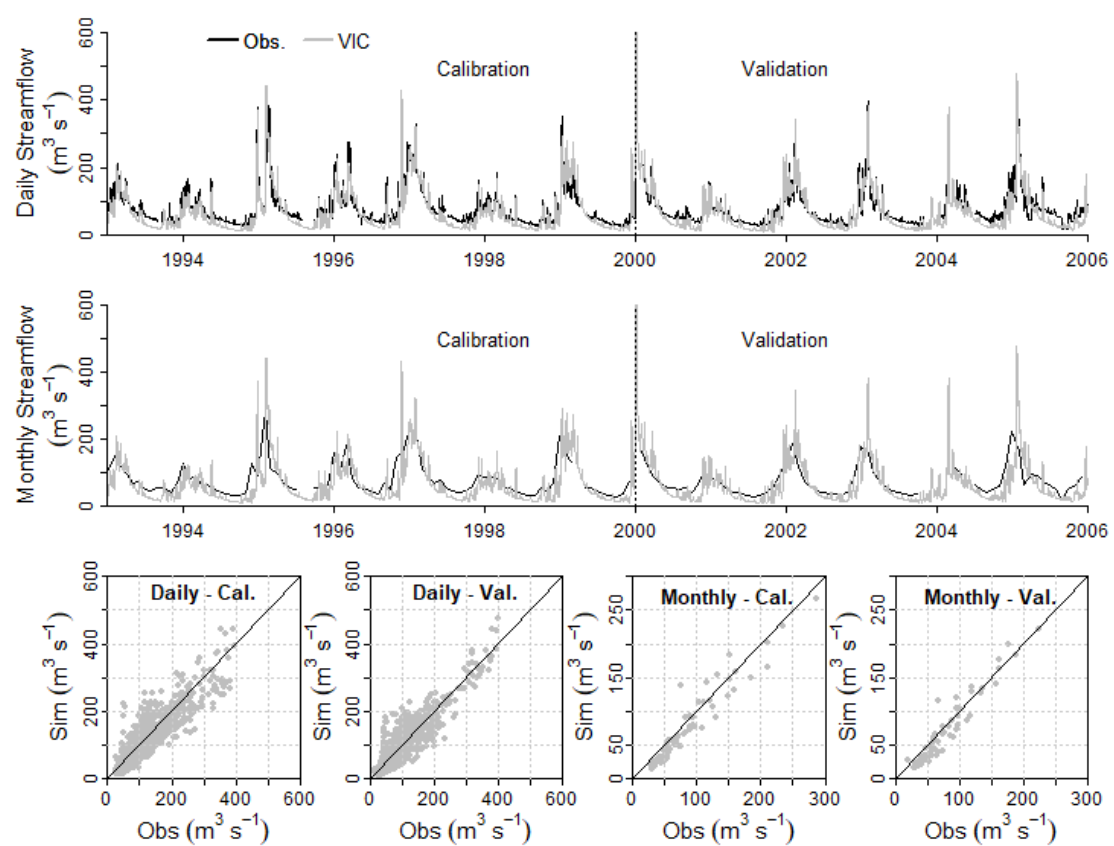

Figure 2. Observed and simulated daily and monthly discharges during calibration (1993-1999) and validation (2000-2005) periods.
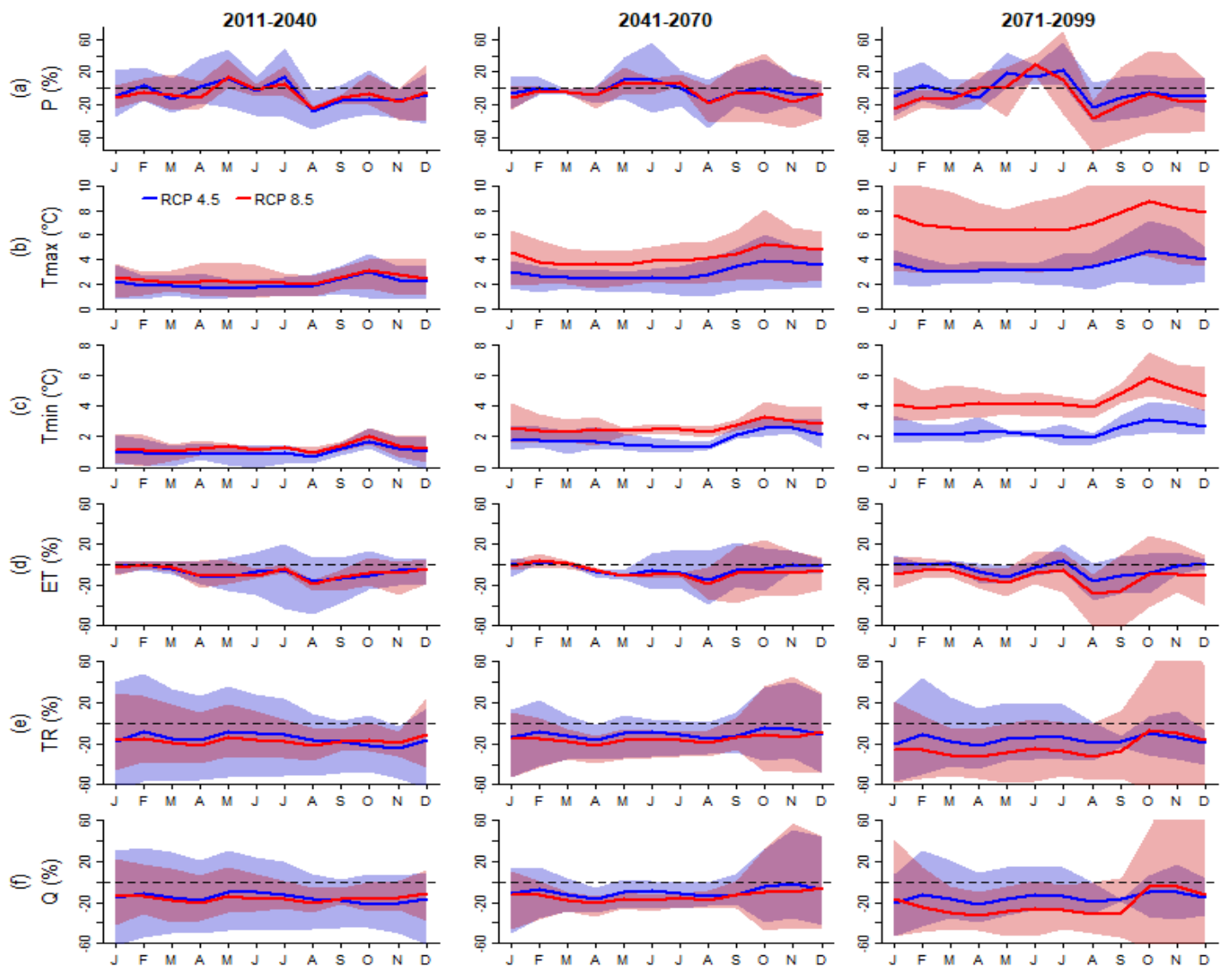

Figure 3. Projected monthly changes in hydrometeorolgical variables of three RCMs (ensemble mean): (a) Precipitation (P); (b) Maximum Temperature (Tmax); (c) Minimum Temperature (Tmin); (d) Evapotranspiration (ET); (e) Total Runoff (TR); and (f) Discharge (Q). P, Tmax and Tmin are derived from meteorological forcing data while ET and TR are simulated by the VIC model and Q by the Routing Model. Each shaded range is bounded by the minimum and maximum of the three RCMs under RCP4.5 (blue) and RCP8.5 (red). 
Regarding the ensemble mean of precipitation (Figure 3a), the RCP4.5 scenario presented a wider range for the 2011 to 2040 period, mainly during the dry season (April-September). On the other hand, the RCP8.5 indicated a wider ensemble range from July to December by the end-century, which may imply impacts on agriculture, reduction of underground recharge, reduction of baseflow and hence water supply during the dry season.

Overall, there is a change in seasonality between radiative scenarios, with the RCP4.5 showing higher variability in the dry season from 2011 to 2040, while RCP8.5 at the beginning of the wet season from 2071 to 2099. At the end of the century, both scenarios showed stronger changes in August, with a reduction of $23.7 \%$ (RCP4.5) and 36.6\% (RCP8.5). Among the RCMs, the Eta simulations driven by HadGEM2-ES showed higher impact in annual precipitation, mainly during the wet season, indicating a reduction of 17.4 and $32.3 \%$ for RCPs 4.5 and 8.5 , respectively.

Maximum temperature (Figure 3b) and minimum temperature (Figure 3c) changes produced similar ensemble ranges in the near-future (2011-2040), indicating minimum difference between radiative scenarios and RCMs. However, at the end of the century, the RCMs projected strong warming in all months, mainly under RCP8.5. From September to January, the ensemble mean showed warming varying from 3.7 to $4.8^{\circ} \mathrm{C}(\mathrm{RCP} 4.5)$ and 7.6 to $8.7^{\circ} \mathrm{C}(\mathrm{RCP} 8.5)$ for maximum temperature, and from 2.3 to $3.1^{\circ} \mathrm{C}(\mathrm{RCP} 4.5)$ and 4.1 to $5.7^{\circ} \mathrm{C}$ (RCP 8.5) for minimum temperature.

Between 2071 and 2099, the Eta-CanESM2 presented increased change in mean annual maximum and minimum temperatures, with a mean increase of 4.7 and $3.1^{\circ} \mathrm{C}$ for $\mathrm{RCP} 4.5$, respectively. Under RCP8.5, the ensemble mean indicated a mean increase of 10.2 and $5.4^{\circ} \mathrm{C}$, respectively. The climate models were highly correlated at near and mid-future; however, the results in the end-future presented a wider range, indicating low reliability.

The ensemble mean of evapotranspiration (Figure 3d) showed similar behavior to that of precipitation, with the RCP4.5 indicating increased variation during the dry season from 2011 to 2040, and RCP8.5 from July to December by the end the century, wherein August and September indicated increased changes with a decrease of 28.6 and 26.0\%, respectively. At the end of the century, the Eta-CanESM2 and Eta-HadGEM2-ES indicated stronger changes in mean annual evapotranspiration under RCP8.5, with a decrease of 20.6 and $21.0 \%$, respectively, while Eta-MIROC5 presented an increase of 9.0\%.

Total runoff (Figure 3e) indicated impacts in all months, with ensemble mean varying from -21.6 to $-10.1 \%$ (RCP4.5) and from -32.7 to $-6.9 \%$ (RCP8.5) by the end of the century (2071 to 2099). The Eta-HadGEM 2 showed stronger decreases in the mean annual total runoff, with reduction of 57.8, 39.2 and $42.3 \%$ under RCP4.5, and 38.2, 41.3, and 54.0\% under RCP8.5 during 2011 to 2040, 2041 to 2070, and 2071 to 2099, respectively.

With the routing model, the ensemble mean of discharge (Figure 3f) showed similar behavior to that of total runoff, indicating negative changes for all months, wherein two first time-slices (2011-2040 and 2041-2070) showed small changes between RCPs 4.5 and 8.5. However, at the end the century, the ensemble mean of RCP8.5 presented a decrease varying from 24.5 to $32.2 \%$ between February and September, while RCP4.5 showed a reduction from 12.4 to $22.0 \%$ for the same period.

Although a three-model ensemble is a limitation in uncertainty analysis in these projections, it gives an indication of the conditions in which models agree or diverge (Chou et al., 2014a). Overall, the models agree in a tendency to increasing maximum and minimum average temperatures. Changes in precipitation estimation over VRB are uncertain. This is also observed in regional scale projections by RCMs worldwide, due to model uncertainty while simulating plants' water-use response to changes of $\mathrm{CO}_{2}$ concentration (Lehner et al., 2019). Thus, changes in simulated discharge and total runoff reflect these uncertainties of precipitation simulations by RCMs (Mello et al., 2021). 
The impacts of climate change on the hydrology of the Verde River Basin are investigated by assessing the changes in mean monthly and annual discharges for three future time-slices (2011-2040, 2041-2070 and 2071-2100) under the RCP4.5 and RCP8.5 scenarios relative to the baseline (1961-2005). Figure 4 shows the mean monthly discharge for the RCMs EtaCanESM2, Eta-HadGEM-ES and Eta-MIROC5, under future projections (RCP4.5 and RCP8.5) and changes relative to the baseline period.

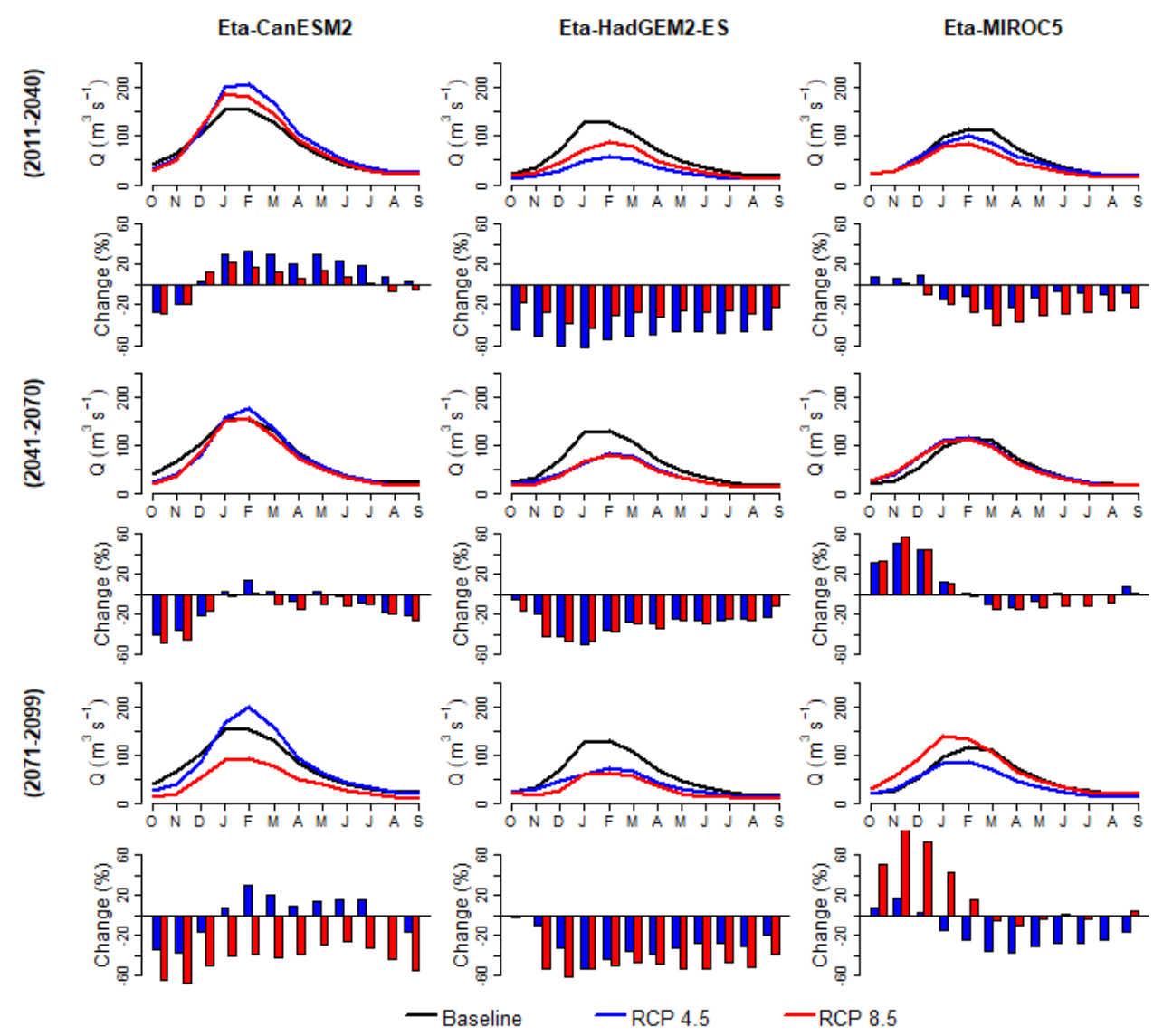

Figure 4. Mean monthly discharge (Q) simulated by the VIC model forced by RCMs Eta-CanESM2, Eta-HadGEM2-ES, and Eta-MIROC5 for the three timeslices (2011-2040, 2041-2070, and 2071-2099) under RCP4.5 (blue) and RCP8.5 (red), and changes (\%) of both scenarios relative to the baseline period (19612005).

At the beginning of the century (2011 to 2040), the annual mean discharge projected based on Eta-MIROC5 decreased 11.7 and 26\% for RCP4.5 and RCP8.5, respectively, whereas EtaCanESM2 indicated an increase of 18.5 and $8.8 \%$ under RCP4.5 and RCP8.5, respectively. The Eta-HadGEM2 showed more impact for all the periods, mainly for the near-future (2011-2040) under RCP4.5 (-53.4\%) and end-century (2071-2099) under RCP8.5 (-49.2\%). This more pronounced impact was expected, since Eta-HadGEM2-ES projected reduction on precipitation throughout the year, especially during the wet season. Thus, other studies have also reported higher impacts by reduced discharge in watersheds over Central and Southeast Brazilian regions based on Eta-HadGEM2-ES (Ribeiro Neto et al., 2016; Oliveira et al., 2017; 2019).

From January to March, the mean monthly discharge of Eta-CanESM2 under RCP4.5 showed an increase for all periods, with changes varying from 29.6 to $33.7 \%$ for the near-future (2011-2040), from 3.0 to $14.2 \%$ for the mid-century (2041-2070), and from 8.1 to $30.5 \%$ for the end-century (2071 to 2099). Also, this behavior was observed in the first time-slice under the RCP8.5 (varying from 12.7 to $22.9 \%$ ). In contrast, at the end of the 21 st century, the Eta- 
CanESM2 under RCP8.5 presented reductions varying from 26.2 to $67.2 \%$, with the beginning of the wet period (October and November) presenting greater impacts.

As opposed to Eta-HadGEM2-ES, the Eta-CanESM2 projections indicate an increase in precipitation during the wet season, especially in RCP4.5. As a result, discharge predictions indicate an increase in the mean monthly value for this season. In a study for watersheds in southern Brazil, Resende et al. (2019) observed an increase in extreme discharge events for RCP4.5 and RCP8.5 scenarios from discharge simulations also using Eta-CanESM2 data.

Regarding Eta-MIROC5, both scenarios showed few changes during the beginning of the wet season (October-December) from 2011 to 2040, varying from 6.7 to 9.1\% (RCP4.5) and 8.9 to $1.4 \%$ (RCP8.5). However, from October to December at the end of the century, the RCP8.5 indicated a stronger increase, ranging from 50.6 to $107.7 \%$, whereas RCP4.5 presented behavior similar for the near-future (2011-2040).

\subsection{FDC Signatures}

Figure 5 shows variability between baseline (1961-2005) and time-slice (2011-2040, 20412070 and 2071-2099) signature indexs of the Flow Duration Curve (FDC) in Verde River Basin, and Figure 6 presents daily discharge simulated by the VIC model using data of future scenarios (RCP4.5 and RCP8.5) projected by the Eta-CanESM2, Eta-HadGEM2-ES, and Eta-MIROC5.
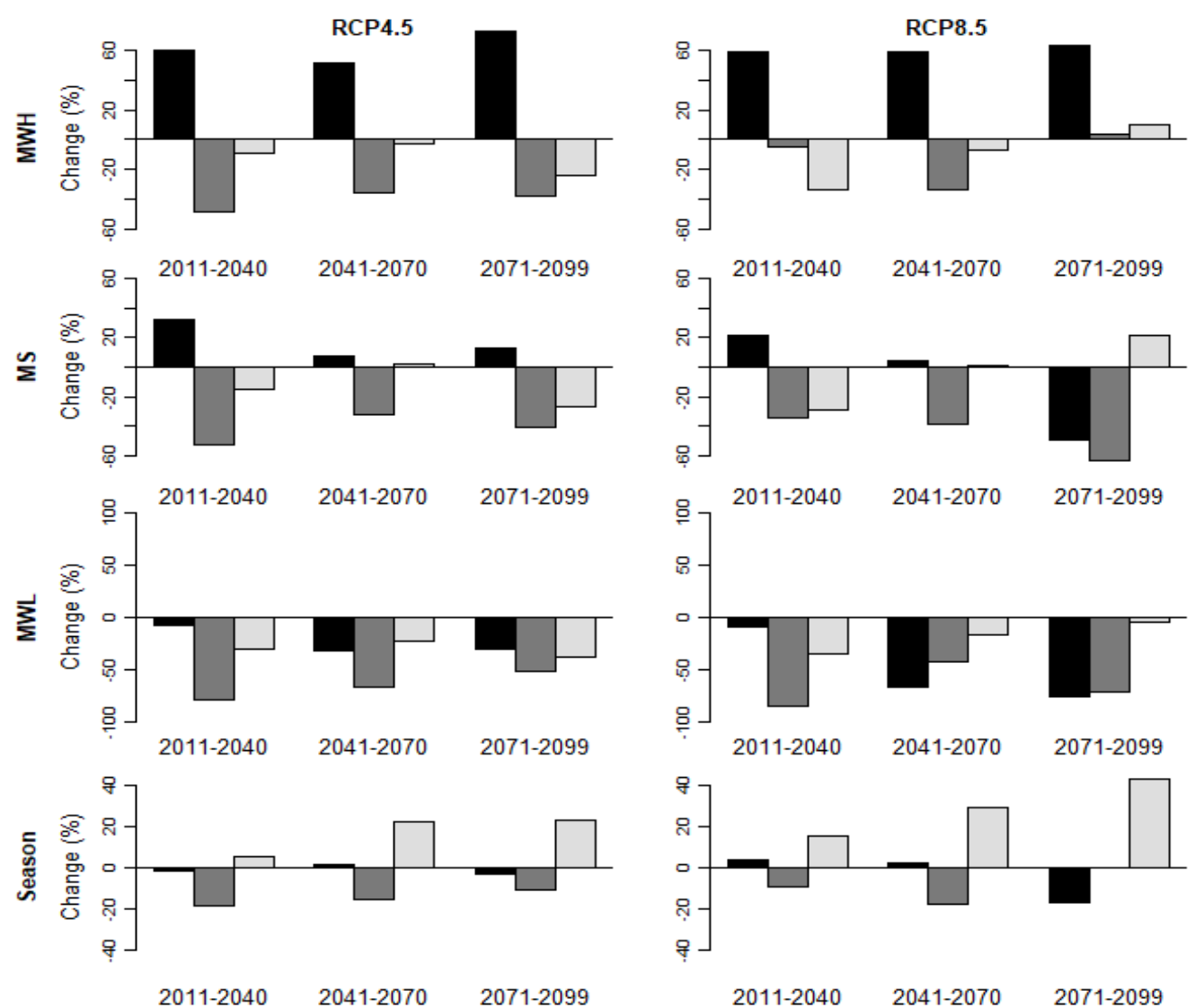

Eta-CanESM2

Eta-HadGEM2-ES Eta-MIROC5

Figure 5. Change (\%) between baseline (1961-2005) and time slices (2011-2040, 2041-2070 and 2071-2099) signatures of the Flow Duration Curve (FDC) in the Verde River Basin. Simulated discharges are the result of hydrological model simulations using data of future scenarios (RCP4.5 and RCP8.5) projected by the RCMs (EtaCanESM2, Eta-HadGEM2-ES and Eta-MIROC5). High flow segment of the FDC (MWH); low flow segment of the FDC (MWL); slope of the FDC at the medium range (MS); differences between wet and dry season discharges (Season). 

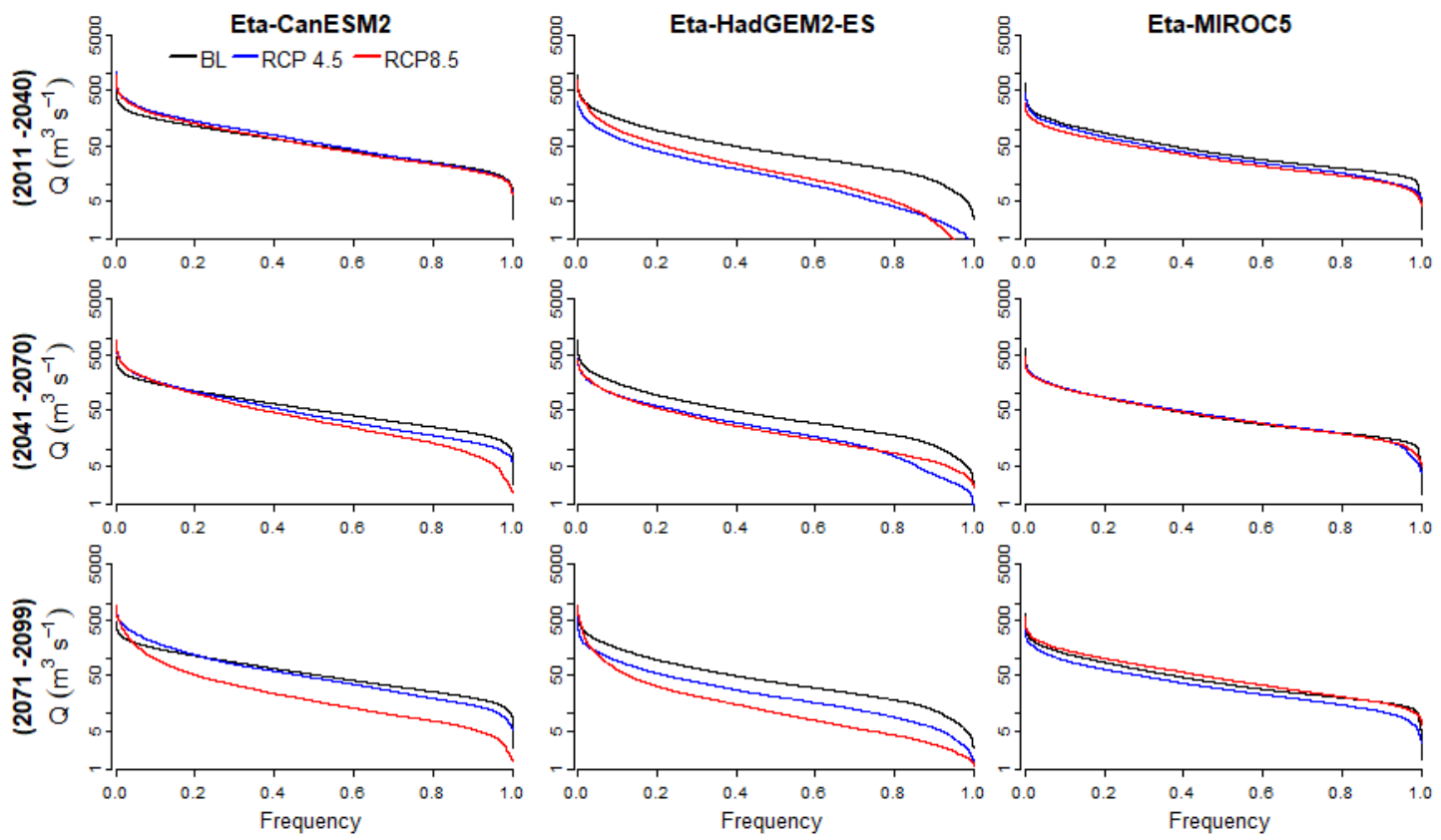

Figure 6. Flow Duration Curve (FDC) of daily discharge (Q) simulated by VIC using data of baseline (BL) and future scenarios (RCP4.5 and RCP8.5) projected by the RCMs (EtaCanESM2, Eta-HadGEM2-ES and Eta-MIROC5).

The basin hydrological response showed an increase towards greater precipitation events under Eta-CanESM2 for all the time-slices, wherein RCP4.5 indicated an increase of 60.3, 52.0 and 73.5\%, and RCP 8.5 increased 58.7, 58.9 and 63.5\% from 2011 to 2040, 2041 to 2070, and 2071 to 2099, respectively. In contrast, the Eta-HadGEM2-ES and Eta-MIROC5 presented a reduction in different magnitudes, except for third time-slice under RCP8.5, which showed an increase of $4.0 \%$ (Eta-HadGEM2-ES) and 10.4\% (Eta-MIROC5). However, there is a consensus among discharge simulations from RCMs projections in the Verde River Basin for the low-flow segment of the FDC (MWL), indicating reduction in dry season discharge. This result is consistent with an Oliveira et al. (2017) study in the Grande River Basin headwaters. Thus, these reductions in the low flow regime in the tropical headwater basin can impact the region with long and extreme droughts (Oliveira et al., 2017).

Concerning the mid-segment slope, the Eta-HadGEM2-ES showed a higher decrease, with MS varying from -32.1 to $-52.5 \%$ under RCP4.5, and from -34.4 to $-63.0 \%$ under RCP8.5. This impact also occurred for the recession flows (MWL), in which Eta-HadGEM2-ES indicated a reduction of $79.2 \%$ (RCP4.5) and 85.6\% (RCP8.5) for near-future (2011-2040), and 51.6\% (RCP4.5) and $72.0 \%$ (RCP8.5) at the end-century (2071-2099). Figure 6 clearly shows the changes in the FDC and steep slope of the curve, indicating lower long-term sustainability of discharge, and, consequently, longer dry periods.

According to Yilmaz et al. (2008), a steep mid-segment slope indicates lower soil storage capacity and, hence, larger surface runoff, while a flatter slope is associated with watersheds having slower groundwater flow response. Moreover, in relation to components of water balance, the Eta-HadGEM2-ES showed larger changes, mainly during the spring season.

Regarding the Season index, the Eta-MIROC5 showed high variability and seasonality, indicating greater difference between the wet and dry seasons of future projections (RCPs 4.5 and 8.5) when compared to the baseline period, which may influence the water supply in the dry season throughout the century. Despite indicating a steep slope of the curve (Figure 6), the EtaHadGEM2-ES presented low variability between seasons (dry and wet) both RCP4.5 and RCP8.5. 
Overall, the Eta-CanESM2 indicated an increase in the maximum discharge (MWH) and a reduction in the recession flows (MWL), i.e., smaller natural-flow regulation capacity, impacting on the water-resource management in the basin. The Eta-MIROC5 showed a slight reduction of MWH, MS and MWL under RCP4.5, and an increase of MWH and MS for RCP8.5 by the end of the century. Regarding the Eta-HadGEM2-ES, the signatures of FDC showed stronger impact on both maximum and minimum discharges.

\section{CONCLUSION}

The VIC was combined with three climate models and two radiative forcing scenarios in order to evaluate the changes in hydrological response in the Grande River Basin and the relative importance of each different input of the hydrological model.

Overall, the VIC model was effective in simulating a micro-scale tropical headwater watershed for climate change studies. This is especially important in studies for large-scale watersheds as the model is able to represent hydrological processes at local conditions, as headwater watersheds are not as monitored in Brazil. The hydrological model showed satisfactory statistical performance, overestimating, however, some peak flows, and underestimating the recession flows.

The ensemble mean of precipitation showed small changes between radiative forcing scenarios. However, in August, precipitation showed a stronger decrease at the end of century in RCPs $4.5(-23.7 \%)$ and $8.5(-36.6 \%)$. Furthermore, for precipitation, only from August to December shows a decrease in mensal values, while in other months the predict change signal is not clear. Regarding temperature changes, the Eta-CanESM2 indicated greater warming, mainly under RCP8.5 at the end of the century, with an increase of 5.4 and $10.2^{\circ} \mathrm{C}$ for mean annual temperature minimum and maximum, respectively. The analysis of uncertainties showed that in general the largest share of uncertainty is related to climate models (the same radiative forcing, different models simulate different changes), and radiative forcing scenarios, due to the uncertainty of future radiative forcing and, hence, climate. Thus, exploring these uncertainties at the regional scale can enhance the reliability of climate change impact projections for watersheds.

The climate model choice remained the dominant factor for mean discharge, as well as in the signatures of the Flow Duration Curve (FDC). Signal of reduction in the majority of the signatures of the FDC is clearer for the simulated discharge using data of Eta-HadGEM2-ES than for the remaining two climate models. Regarding mean monthly discharge, the EtaHadGEM2-ES showed higher reductions for all periods under both radiative forcing scenarios, wherein RCP4.5 presented more impact at the beginning of the century, and under RCP8.5, at the end of the century. The results indicated high vulnerability of the region regarding water uses in the future, mainly for Eta-HadGEM2-ES projections, negatively impacting water availability, agriculture and livestock production, and potential for hydro-electric generation.

\section{ACKNOWLEDGEMENTS}

This work was supported by Conselho Nacional de Desenvolvimento Científico e Tecnológico (Process 429247/2018-4).

\section{REFERENCES}

ALVARENGA, L. A.; MELlO, C. R. de; COLOMBO, A.; CUARTAS, L. A.; BOWLING, L. C. Assessment of land cover change on the hydrology of a Brazilian headwater watershed using the Distributed Hydrology-Soil-Vegetation Model. Catena, Amsterdam, v. 143, p. 7-17, 2016a. https://doi.org/10.1016/j.catena.2016.04.001 
ALVARENGA, L. A.; MELlO, C. R. de; COLOMBO, A.; CHOU, S. C.; CUARTAS, L. A.; VIOLA, M. R. Hydrological responses to climate changes in a headwater watershed. Ciência e Agrotecnologia, Lavras, v. 40, n. 6, p. 647-657, $2016 \mathrm{~b}$. https://doi.org/10.1590/1413-70542016406027716

ALVARENGA, L. A.; MELlO, C. R. de; COLOMBO, A.; CUARTAS, L. A.; ALVARENGA, L. A.; MELLO, C. R. de et al. Hydrologic impacts due to the changes in riparian buffer in a headwater watershed. CERNE, Lavras, v. 23, n. 1, p. 95-102, 2017. https://doi.org/10.1590/01047760201723012205

ALVARENGA, L. A.; MELlO, C. R. de; COLOMBO, A.; CUARTAS, L. A.; CHOU, S. C. Impacts of Climate Change on the Hydrology of a Small Brazilian Headwater Catchment Using the Distributed Hydrology-Soil-Vegetation Model. American Journal of Climate $\begin{array}{lllllll}\text { Change, } & \text { Irvine, } & \text { v. } 7, \quad \text { n. } & \text { 2, p. 355-366, }\end{array}$ http://www.scirp.org/journal/PaperInformation.aspx?PaperID=85669\&\#abstract

ARORA, V. K.; SCINOCCA, J. F.; BOER, G. J.; CHRISTIAN, J. R.; DENMAN, K. L.; FLATO, G. M. et al. Carbon emission limits required to satisfy future representative concentration pathways of greenhouse gasses. Geophysical Research Letters, Washington, v. 38, n. 5, 2011. https://doi.org/10.1029/2010GL046270

BLACK, T. L. The New NMC Mesoscale Eta Model: Description and Forecast Examples. Weather and Forecasting, Boston, v. 9, n. 2, p. 265-278, 1994. https://doi.org/10.1175/1520-0434(1994)009\%3C0265:TNNMEM\%3E2.0.CO;2

BUENO, E. de O.; ALVES, G. J.; MELLO, C. R. Hydroelectricity water footprint in Parana Hydrograph Region, Brazil. Renewable Energy, Amsterdam, v. 162, p. 596-612, 2020. https://doi.org/10.1016/j.renene.2020.08.047

BOZKURT, D.; ROJAS, M.; BOISIER, J. P.; VALDIVIESO, J. Climate change impacts on hydroclimatic regimes and extremes over Andean basins in central Chile. Hydrology and Earth System Sciences, Munich, p. 1-29, 2017. https://doi.org/10.5194/hess-2016-690

BYUN, K.; CHIU, C.-M.; HAMLET, A. F. Effects of 21st century climate change on seasonal flow regimes and hydrologic extremes over the Midwest and Great Lakes region of the US. Science of The Total Environment, Amsterdam, v. 650, p. 1261-1277, 2019. https://doi.org/10.1016/j.scitotenv.2018.09.063

CHAWLA, I.; MUJUMDAR, P. P. Isolating the impacts of land use and climate change on streamflow. Hydrology and Earth System Sciences, Munich v. 19, n. 8, p. 3633-3651, 2015. https://doi.org/10.5194/hess-19-3633-2015

CHOU, S. C.; MARENGO, J. A.; LYRA, A. A.; SUEIRO, G.; PESQUERO, J. F.; ALVES, L. M. et al. Downscaling of South America present climate driven by 4-member HadCM3 runs. Climate Dynamics, Cham, v. 38, n. 3, p. 635-653, 2012. https://doi.org/10.1007/s00382-011-1002-8

CHOU, S. C.; LYRA, A.; MOURÃO, C.; DERECZYNSKI, C.; PILOTTO, I.; GOMES, J. et al. Evaluation of the Eta Simulations Nested in Three Global Climate Models. American Journal of Climate Change, Irvine, v. 3, n. 5, p. 438-454, 2014a. https://doi.org/10.4236/ajcc.2014.35039 
CHOU, S. C.; LYRA, A.; MOURÃO, C.; DERECZYNSKI, C.; PILOTTO, I.; GOMES, J. et al. Assessment of Climate Change over South America under RCP 4.5 and 8.5 Downscaling Scenarios. American Journal of Climate Change, Irvine, v. 3, n. 5, p. 512-527, 2014b. https://doi.org/10.4236/ajcc.2014.35043

CHOU, S. C.; LYRA, A.; CHAGAS, D.; DERECZYNSKI, C.; GOMES, J.; TAVARES, P. Downscaling projections of climate change over South America and Central America under RCP4.5 and RCP8.5 emission scenarios. In: 20TH EGU GENERAL ASSEMBLY, 2018, Vienna. Anais [...]. Vienna: EGU2018, 2018. p. 8866.

CLARKE, L. E.; JACOBY, H.; PITCHER, H.; REILLY, J.; RICHELS, R. Sub-Report 2.1a of Synthesis and Assessment Product 2.1. In: US CLIMATE CHANGE SCIENCE PROGRAM. Scenarios of Greenhouse Gas Emissions and Atmospheric. Washington: Office of Biological \& Environmental Research, 2007. p. 164.

COLLINS, W. J.; BELLOUIN, N.; DOUTRIAUX-BOUCHER, M.; GEDNEY, N.; HALLORAN, P.; HINTON, T. et al. Development and evaluation of an Earth-System model - HadGEM2. Geoscientific Model Development, Munich, v. 4, n. 4, p. 10511075, 2011. https://doi.org/10.5194/gmd-4-1051-2011

DANG, T. D.; CHOWDHURY, A. F. M. K.; GALELLI, S. On the representation of water reservoir storage and operations in large-scale hydrological models: implications on model parameterization and climate change impact assessments. Hydrology and Earth System Sciences, Munich, v. 24, n. 1, p. 397-416, 2020. https://doi.org/10.5194/hess-24397-2020

GRAHAM, L. P.; ANDRÉASSON, J.; CARLSSON, B. Assessing climate change impacts on hydrology from an ensemble of regional climate models, model scales and linking methods - A case study on the Lule River basin. Climatic Change, Cham, v. 81, p. 293307, 2007. https://doi.org/10.1007/s10584-006-9215-2

GUPTA, H. V.; SOROOSHIAN, S.; YAPO, P. O. Status of Automatic Calibration for Hydrologic Models: Comparison with Multilevel Expert Calibration. Journal of Hydrologic Engineering, Reston, v. 4, n. 2, p. 135-143, 1999. https://doi.org/10.1061/(ASCE)1084-0699(1999)4:2(135)

GUPTA, H. V.; KLING, H.; YILMAZ, K. K.; MARTINEZ, G. F. Decomposition of the mean squared error and NSE performance criteria: Implications for improving hydrological modeling. Journal of Hydrology, Amsterdam, v. 377, n. 1, p. 80-91, 2009. https://doi.org/10.1016/j.jhydrol.2009.08.003

HADDELAND, I.; HEINKE, J.; VOSS, F.; EISNER, S.; CHEN, C.; HAGEMANN, S.; LUDWIG, F. Effects of climate model radiation, humidity and wind estimates on hydrological simulations. Hydrology and Earth System Sciences, Munich, v. 16, p. 305-318, 2012. https://doi.org/10.5194/hess-16-305-2012

IPCC. Climate Change 2013 - The Physical Science Basis: Working Group I Contribution to the Fifth Assessment Report of the Intergovernmental Panel on Climate Change. Cambridge: Cambridge University Press, 2014.

KNUTTI, R.; SEDLÁČEK, J. Robustness and uncertainties in the new CMIP5 climate model projections. Nature Climate Change, London, v. 3, n. 4, p. 369-373, 2013. https://doi.org/10.1038/nclimate1716 
LEHNER, F. et al. The potential to reduce uncertainty in regional runoff projections from climate models. Nature Climate Change, London, v. 9, n. 12, p. 926-933, 2019. https://doi.org/10.1038/s41558-019-0639-X

LENDERINK, G.; BUISHAND, A.; VAN DEURSEN, W. Estimates of future discharges of the river Rhine using two scenario methodologies: Direct versus delta approach. Hydrology and Earth System Sciences, Munich, v. 11, n. 3, p. 1145-1159, 2007. https://doi.org/10.5194/hess-11-1145-2007

LEY, R.; CASPER, M. C.; HELLEBRAND, H.; MERZ, R. Catchment classification by runoff behaviour with self-organizing maps (SOM). Hydrology and Earth System Sciences, Munich, v. 15, n. 9, p. 2947-2962, 2011. https://doi.org/10.5194/hess-15-2947-2011

LIANG, X.; LETTENMAIER, D. P.; WOOD, E. F.; BURGES, S. J. A simple hydrologically based model of land surface water and energy fluxes for general circulation models. Journal of Geophysical Research: Atmospheres, Washington, v. 99, n. D7, p. 1441514428, 1994. https://doi.org/10.1029/94JD00483

LIANG, X.; WOOD, E. F.; LETTENMAIER, D. P. Surface soil moisture parameterization of the VIC-2L model: Evaluation and modification. Global and Planetary Change, Amsterdam, v. 13, n. 1, Soil Moisture Simulation, p. 195-206, 1996. https://doi.org/10.1016/0921-8181(95)00046-1

LIANG, X.; XIE, Z. A new surface runoff parameterization with subgrid-scale soil heterogeneity for land surface models. Advances in Water Resources, Amsterdam, v. 24, n. 9-10, p. 1173-1193, 2001. https://doi.org/10.1016/S0309-1708(01)00032-X

LOHMANN, D.; RASCHKE, E.; NIJSSEN, B.; LETTENMAIER, D. P. Regional scale hydrology: II. Application of the VIC-2L model to the Weser River, Germany. Hydrological Sciences Journal, London, v. 43, n. 1, p. 143-158, 1998. https://doi.org/10.1080/02626669809492108

LOHMANN, D.; NOLTE-HOLUBE, R.; RASCHKE, E. A large-scale horizontal routing model to be coupled to land surface parameterization schemes. Tellus A: Dynamic Meteorology and Oceanography, London, v. 48, n. 5, p. 708-721, 1996. https://doi.org/10.1034/j.1600-0870.1996.t01-3-00009.x

MARENGO, J. A. O quarto relatório do ipcc (ipcc ar4) e projeções de mudança de clima para o brasil e américa do sul. Boletim da Sociedade Brasileira de Meteorologia, Rio de Janeiro, v. 31, n. 1, p. 23-28, 2007.

MARENGO, J. A.; CHOU, S. C.; KAY, G.; ALVES, L. M.; PESQUERO, J. F.; SOARES, W. R. et al. Development of regional future climate change scenarios in South America using the Eta CPTEC/HadCM3 climate change projections: climatology and regional analyses for the Amazon, São Francisco and the Paraná River basins. Climate Dynamics, Cham, v. 38, n. 9, p. 1829-1848, 2012. https://doi.org/10.1007/s00382-011-1155-5

MARTIN, G. M.; BELLOUIN, N.; COLLINS, W. J.; CULVERWELL, I. D.; HALLORAN, P. R.; HARDIMAN, S. C. et al. The HadGEM2 family of Met Office Unified Model climate configurations. Geoscientific Model Development, Munich, v. 4, n. 3, p. 723-757, 2011. https://doi.org/10.5194/gmd-4-723-2011

Rev. Ambient. Água vol. 17 n. 1, e2753 - Taubaté 2022 
MELLO, C. R. de; NORTON, L. D.; CURI, N.; YANAGI, S. N. M. Sea surface temperature (SST) and rainfall erosivity in the Upper Grande River Basin, southeast Brazil. Ciência e Agrotecnologia, Lavras, v. 36, n. 1, p. 53-59, 2012. https://doi.org/10.1590/S141370542012000100007

MELLO, C. R. et al. Climate Change Impacts on Water Resources of the Largest Hydropower Plant Reservoir in Southeast Brazil. Water, Basel, v. 13, n. 11, p. 1560, 2021. https://doi.org/10.3390/w13111560

MESINGER, F.; CHOU, S. C.; GOMES, J. L.; JOVIC, D.; BASTOS, P.; BUSTAMANTE, J. F. et al. An upgraded version of the Eta model. Meteorology and Atmospheric Physics, Cham, v. 116, n. 3, p. 63-79, 2012. https://doi.org/10.1007/s00703-012-0182-z

MORIASI, D. N.; ARNOLD, J. G.; VAN LIEW, M. W.; BINGNER, R. L.; HARMEL, R. D.; VEITH, T. L. Model Evaluation Guidelines for Systematic Quantification of Accuracy in Watershed Simulations. American Society of Agricultural and Biological Engineers, St. Joseph, v. 50, n. 3, p. 885-900, 2007. https://doi.org/10.13031/2013.23153

NASH, J. E.; SUTCLIFFE, J. V. River flow forecasting through conceptual models part I - A discussion of principles. Journal of Hydrology, Amsterdam, v. 10, n. 3, p. 282-290, 1970. https://doi.org/10.1016/0022-1694(70)90255-6

NOBRE, P.; OYAMA, M. D.; OLIVEIRA, G. S.; TOMASELLA, J. Impactos de mudanças climáticas globais na hidrologia do semiárido do Nordeste brasileiro para o final do século XXI. In: MEDEIROS, S. de S. et al. (eds.). Recursos Hídricos em Regiões Áridas e Semiáridas. Campina Grande: Instituto Nacional do Semiárido, 2011. p. 423-437.

OLIVEIRA, V. A. de; MELLO, C. R. de; VIOLA, M. R.; SRINIVASAN, R. Assessment of climate change impacts on streamflow and hydropower potential in the headwater region of the Grande river basin, Southeastern Brazil. International Journal of Climatology, Reading, v. 37, n. 15, p. 5005-5023, 2017. https://doi.org/10.1002/joc.5138

OLIVEIRA, V. A. de; MELLO, C. R. de; VIOLA, M. R.; SRINIVASAN, R. Land-Use Change Impacts On The Hydrology Of The Upper Grande River Basin, Brazil. CERNE, Lavras, v. 24, n. 4, p. 334-343, 2018. https://doi.org/10.1590/01047760201824042573

OLIVEIRA, V. A. de; MELLO, C. R. de; BESKOW, S.; VIOLA, M. R.; SRINIVASAN, R. Modeling the effects of climate change on hydrology and sediment load in a headwater basin in the Brazilian Cerrado biome. Ecological Engineering, Amsterdam, v. 133, p. 20-31, 2019. https://doi.org/10.1016/j.ecoleng.2019.04.021

PESQUERO, J. F.; CHOU, S. C.; NOBRE, C. A.; MARENGO, J. A. Climate downscaling over South America for 1961-1970 using the Eta Model. Theoretical and Applied Climatology, Cham, v. 99, n. 1, p. 75-93, 2010. https://doi.org/10.1007/s00704-0090123-Z

RAJIB, M. A.; RAHMAN, M. M. A Comprehensive Modeling Study on Regional Climate Model (RCM) Application - Regional Warming Projections in Monthly Resolutions under IPCC A1B Scenario. Atmosphere, Basel, v. 3, n. 4, p. 557-572, 2012. https://doi.org/10.3390/atmos3040557

RESENDE, N. C.; MIRANDA, J. H.; COOKE, R.; CHU, M. L.; CHOU, S. C. Impacts of regional climate change on the runoff and root water uptake in corn crops in Parana, Brazil. Agricultural Water Management, Amsterdam, v. 221, p. 556-565, 2019. https://doi.org/10.1016/j.agwat.2019.05.018 
RIAHI, K.; RAO, S.; KREY, V.; CHO, C.; CHIRKOV, V.; FISCHER, G.; KINDERMANN, G. et al. RCP 8.5-A scenario of comparatively high greenhouse gas emissions. Climatic Change, Cham, v. 109, n. 1, p. 33, 2011. https://doi.org/10.1007/s10584-011-0149-y

RIBEIRO NETO, A.; DA PAZ, A. R.; MARENGO, J. A.; CHOU, S. C. Hydrological Processes and Climate Change in Hydrographic Regions of Brazil. Journal of Water Resource

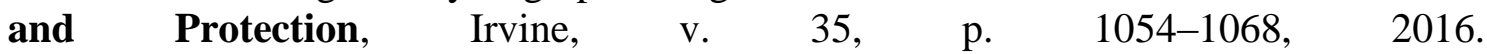
https://doi.org/10.4236/jwarp.2016.812087

RODRIGUES, J. A. M.; VIOLA, M. R.; ALVARENGA, L. A.; MELLO, C. R. de; CHOU, S. C.; OLIVEIRA, V. A. de et al. Climate change impacts under representative concentration pathway scenarios on streamflow and droughts of basins in the Brazilian Cerrado biome. International Journal of Climatology, Reading, v. 40, n. 5, p. 25112526, 2020. https://doi.org/10.1002/joc.6347

TAYLOR, K. E.; STOUFFER, R. J.; MEEHL, G. A. An Overview of CMIP5 and the Experiment Design. Bulletin of the American Meteorological Society, Boston, v. 93, n. 4, p. 485-498, 2012. https://doi.org/10.1175/BAMS-D-11-00094.1

TEUTSCHBEIN, C.; SEIBERT, J. Bias correction of regional climate model simulations for hydrological climate-change impact studies: Review and evaluation of different methods. Journal of Hydrology, Amsterdam, v. 456-457, p. 12-29, 2012. https://doi.org/10.1016/j.jhydrol.2012.05.052

THOMSON, A. M.; CALVIN, K. V.; SMITH, S. J.; KYLE, G. P.; VOLKE, A.; PATEL, P. et al. RCP4.5: a pathway for stabilization of radiative forcing by 2100. Climatic Change, Cham, v. 109, n. 1, p. 77, 2011. https://doi.org/10.1007/s10584-011-0151-4

TODINI, E. The ARNO rainfall—runoff model. Journal of Hydrology, Amsterdam, v. 175, n. 1, p. 339-382, 1996. https://doi.org/10.1016/S0022-1694(96)80016-3

VAN VUUREN, D. P.; EDMONDS, J.; KAINUMA, M.; RIAHI, K.; THOMSON, A.; HIBBARD, K. et al. The representative concentration pathways: an overview. Climatic Change, Cham, v. 109, n. 1, p. 5, 2011. https://doi.org/10.1007/s10584-011-0148-z

VIOLA, M. R.; MELLO, C. R.; BESKOW, S.; NORTON, L. D. Impacts of Land-use Changes on the Hydrology of the Grande River Basin Headwaters, Southeastern Brazil. Water Resources Management, Cham, v. 28, n. 13, p. 4537-4550, 2014. https://doi.org/10.1007/s11269-014-0749-1

VIOLA, M. R.; MELLO, C. R. de; CHOU, S. C.; YANAGI, S. N.; GOMES, J. L. Assessing climate change impacts on Upper Grande River Basin hydrology, Southeast Brazil. International Journal of Climatology, Reading, v. 35, n. 6, p. 1054-1068, 2015. https://doi.org/10.1002/joc.4038

WANG, H.; XIAO, W.; WANG, Y.; ZHAO, Y.; LU, F.; YANG, M. et al. Assessment of the impact of climate change on hydropower potential in the Nanliujiang River basin of $\begin{array}{lllll}\text { China. Energy, Amsterdam, v. 167, p. 950-959, } 2019 . & \text {. }\end{array}$ https://doi.org/10.1016/j.energy.2018.10.159

WATANABE, M.; SUZUKI, T.; O'ISHI, R.; KOMURO, Y.; WATANABE, S.; EMORI, S. et al. Improved Climate Simulation by MIROC5: Mean States, Variability, and Climate Sensitivity. Journal of Climate, Boston, v. 23, n. 23, p. 6312-6335, 2010. https://doi.org/10.1175/2010JCLI3679.1 
WISE, M.; CALVIN, K.; THOMSON, A.; CLARKE, L.; BOND-LAMBERTY, B.; SANDS, R. et al. Implications of Limiting CO2 Concentrations for Land Use and Energy. Science, $\begin{array}{llllll}\text { Washington, } & \text { v. } 324, \quad \text { n. } 5931, \quad \text { p. }\end{array}$ https://doi.org/10.1126/science. 1168475

YANG, X.; YU, X.; WANG, Y.; LIU, Y.; ZHANG, M.; REN, L. et al. Estimating the response of hydrological regimes to future projections of precipitation and temperature over the upper Yangtze River. Atmospheric Research, Amsterdam, v. 230, p. 104627, 2019. https://doi.org/10.1016/j.atmosres.2019.104627

YILMAZ, K. K.; GUPTA, H. V.; WAGENER, T. A process-based diagnostic approach to model evaluation: Application to the NWS distributed hydrologic model. Water

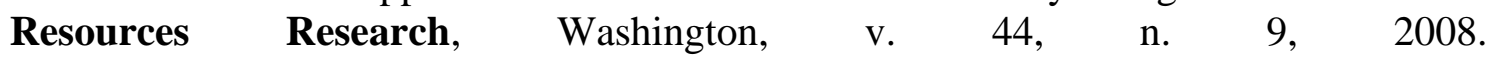
https://doi.org/10.1029/2007WR006716 